\title{
Assessing the role of urban green spaces for human well- being: a systematic review
}

\author{
Muhammad Jabbar (D) Mariney Mohd Yusoff • Aziz Shafie
}

Accepted: 12 July 2021 / Published online: 20 July 2021

(C) The Author(s), under exclusive licence to Springer Nature B.V. 2021

\begin{abstract}
Human has been evolving in a natural environment over a long time; thus, he is habitual to adapt it. Green spaces are obligatory landscapes in an urban structure that provide a natural environment and accelerate other life events. In contrast, unplanned urbanization, and conversion from green to grey structures have damaged natural environmental resources. Studies through different angles have highlighted the importance of urban green spaces for human well-being but now need to identify their role according to the potential. The demands of urban green spaces may differ with the change of population size, types of grey structure, urban expansion, the altitude of the place, and geographical location. Therefore, this systematic review aims to analyse the significance of urban green spaces for human wellbeing. The study opted for a systematic process during the selection and organization of studies for this review. After analysing, 46 studies were finalized with
\end{abstract}

M. Jabbar $(\square)$

University of Malaya, Kuala Lumpur, Malaysia

e-mail: jabbar.lhr@gmail.com

M. M. Yusoff

Geography Department, University of Malaya,

Kuala Lumpur, Malaysia

e-mail: mariney@um.edu.my

A. Shafie

HOD Geography Department, University of Malaya,

Kuala Lumpur, Malaysia

e-mail: azizs@um.edu.my the consensus of three review authors. Accordingly, literature was analysed under the central theme of "Urban Green Spaces for Human Well-being." Human Well-being was assessed under six subthemes; physical, psychological, mental, social, subjective, and environmental well-being. The review concluded that urban green spaces are the primary pillar for a sustainable urban place and human wellbeing due to highly positive and positive correlations. Moreover, the study did not find any demarcation line between green spaces and grey structures according to any specific need. Therefore, the study suggested that the role of urban green spaces for human well-being should be analysed according to their potential and required optimal ratio under different communities' urban specific environments and social behaviour.

Keywords Urban green spaces · Human well-being · Environmental sustainability $\cdot$ Social behaviour

\section{Introduction}

Urban Green Space is a sum of green paved, open and burial places, sports grounds, private gardens, formal and informal green forests, road verges, derelict land, and horticulture within a city (Duan et al., 2018; Wang $\&$ Akbari, 2016). Human life exists on the earth due to its suitable natural environment and other living 
things. These living things are a source of fresh air and water, fruit, woods, animals, and minerals to fulfil daily life needs (Baycan et al., 2012). They provide a natural meeting point for the residents by facilitating social interaction and community integration. Green spaces accelerate a sense of individuality and belongings (Konijnendijk et al., 2013). The density of vegetation enhances the ability of urban green spaces to mitigate air pollution (Dadvand et al., 2015). Green infrastructure is one of the significant pillars of urban structures that accelerates human life events by promoting physical activities, mental and psychological relaxation, oxygen for breathing, and purifying air pollutants. Urban greenness offers a safe and healthy space for walking, jogging, and running, provides a suitable environment for physical and recreational activities and social interaction (WHO|Urban Green Spaces, n.d.).

Human Well-being is recognized to measure human conditions like human health, education, and material of livening standards. In the beginning, the concept was known as the Human Development Index (HDI) toward human conditions (Bhanojirao, 1991; Desai, 1991; McGillivray \& White, 1993). The HDI concept became more comprehensive with time and appeared as a Sustainable Livelihood Approach (SLA) in 1992 by Chamber and Conway, an actionable framework combining social, economic, environmental, and institutional components (Chambers \& Conway, 1992). Further, the SLA concept changed into Millennium Development Goals (MDG), and it was measured with education, gender equality, health, environment, poverty, and hunger indicators (Gwatkin, 2002; Hopkins, 1991). In this review, the concept "Human Well-being" is obtained as "a state of human being that comprises on human (physical, psychological, mental) health, good social interaction, and overall life satisfaction (Subjective Well-being).

Green spaces are well documented for socioeconomic and environmental benefits in urban areas by enhancing the natural environment and human health. Physical comfort, psychological and emotional relaxation, and social interaction are found due to urban green spaces in quality of life models (Mensah et al., 2016). The role of urban green spaces has been recognized as a primary source of a livable and sustainable city (Dhingra \& Chattopadhyay, 2016). Urban Greenness improves human life actively by mitigating the urban heat island densely populated areas. The significance of urban green spaces has been analysed for better human life through leisure activities, social interaction, noise reduction, and removal of air pollution (Wolch et al., 2014). The requirement of ecosystem services on a broad scale is delivered by the urban green spaces for inhabitants and the city environment. In a city, green landscapes have a pivotal potential to maintain a sustainable environment and activate cultural events. Well-managed urban green landscapes are estimated more significant for provisioning ecosystem services (freshwater, food, and raw material) in Vilnius (Lithuania).

Functionally, urban green spaces absorb $\mathrm{CO}_{2}$, release $\mathrm{O}_{3}$, decrease the temperature, reduce urban heat island effects, enhance air quality and humidity, conserve soil and water, minimize noise pollution, cut down winds speed, and save soil from contaminations and erosion (Lou et al., 2017). The occurrence of urban green spaces mitigates climatic change effects, provides a platform for social connection, and enhances human health and well-being (Krellenberg et al., 2014). Green spaces deliver several positive health impacts through physical activities (Sanders et al., 2015). Also, under the COVID-19 crisis, urban green spaces were a significant source of leisure activities. Outside events were reported $291 \%$ higher during lock-down than the past 3 years over the same day in Oslo (Norway). Walking, jogging, and hiking practises in urban parks have expanded, emphasising relevance of urban green spaces during the crisis (Venter et al., 2020). Open green spaces brought considerable social benefits in Spain during the Fadura Thinking project in Getxo. The proximity to urban parks to lower socio-economic status and vulnerable groups with improved leisure activities was found the most advantageous. In contrast, noise and poor cleanliness are the most damaging effects of crime and possible tension for the general public (García de Jalón et al., 2020). By providing trails and benches with a canopy of vegetation, the benefits of urban green spaces can be improved (Madureira et al., 2018).

Urban societies demanded proper management and more urban green spaces (Campagnaro et al., 2020). It was evaluated that authentic fitness was linked with physical recreation activity. The appearance and convenient access to green spaces also found supportive for life satisfaction and health promotion. More links of walking and cycling are found to public health in urban and suburban areas within urban green spaces 
(Pietilä et al., 2015; Zhong et al., 2020). Good physical fitness also helps to regular parks visit. Social harmony and leisure facilities have been proposed as an attractive source of human well-being to locals. The interconnection of socio-ecological structures in urban green areas may improve socio-environmental justice by focusing on ecosystem services (Enssle \& Kabisch, 2020). The frequency of parks visits rises with a better quality of urban parks for human and environmental health (Misiune et al., 2021). The activity in green spaces determines advantages; walk reduces fatigue and sitting safer for restoring attention (Lin et al., 2020). In order to improve human health, better biophysical properties of canopy vegetation in urban areas are necessary. Improved green landscapes and their connectivity increases health benefits and decreases disease morbidity (Yeh et al., 2020).

After reviewing previous studies, it has been found that most urban areas are not environmentally suitable for living due to the shrinking of green spaces and expansion of the built-up structure. Therefore, it is more disastrous to expand such urban areas still similarly. Hence, this study reviews previous literature on the significance of urban green spaces for human (physical, psychological, mental, social, and subjective) well-being. Therefore, the study aims to:

- Review previous literature on the role of urban green spaces for human well-being.

\section{Methods}

In this review, 46 publications from the Web of Science and Scopus index and PubMed databases were finalized by the authors. These 46 studies were found well cited in the different studies. All these 46 publications received 3732 citations collectively by May 2021. Table 2 shows the citation detail of each paper. A process of searching and organization the data is given below:

\section{Sources of data}

The data for this systematic review were collected from Web of Science, Scopus, and PubMed databases. Web of Science is temporally working since 1900, which was established by Clarivate Analytics. It consists of almost 256 disciplines, including sciences, social sciences, arts, and humanities. Scopus is the second source of this review's data, covering almost 27 major and more than 300 minor disciplines like physical, health, life, and social sciences published by Elsevier. While PubMed is the third data source of this article, MEDLINE databases' primary search engine deals with life sciences and biomedical-based data. It was established in January 1996 and contained peerreviewed biomedical journals with more than 30 million citations. These three databases provide Advanced Search Tool, which eases to find the related result concisely. The searched data was collected according to the study themes and retrieved in the system e-library. The retrieved data was imported into Zotero software to detect and remove duplicates.

\section{Searching strategy}

This systematic review depicts the relations between urban green spaces and human (physical, psychological, mental, social, subjective, and environmental) well-being. For searching the relevant literature, retrieval queries were developed. First, relevant literature was identified and collected by using the given keywords in Table 1:

\section{Eligibility criteria}

The studies were retrieved using predetermined criteria. The identification and screening processes were conducted with the authors' consensus. A total of 713 research articles was found under the study themes, including 174 duplicates. One hundred seventy-four duplicates and 157 non-urban studies were excluded according to the predetermined criteria. After that, the remaining 382 studies were evaluated for initial screening. Therefore, 147 articles were excluded after reviewing the abstracts and 189 after reviewing the full text if they were: (1) not match the theme, (2) not fulfil the demand of study objective, (3) not focused on urban green spaces with relations to human (physical, psychological, mental, social, subjective, and environmental) well-being and (5) not belong to peerreviewed journals. At last, 46 studies were finalized for this review (Fig. 1). 
Table 1 Queries used for searching the data

\begin{tabular}{|c|c|}
\hline Databases & Keywords \\
\hline $\begin{array}{l}\text { Web of } \\
\text { science }\end{array}$ & $\begin{array}{l}\text { 'TS = (("urban green spaces*” OR "urban greenness" OR “urban green infrastructure" OR "urban vegetation" OR } \\
\text { "urban parks")) and ("human well-being*" OR "quality of life*" OR "physical* well-being" OR "physical } \\
\text { health" OR "psychological* well-being" OR "psychological health" OR "mental* well-being" OR "mental } \\
\text { health" OR "social* well-being" OR "social cohesion" OR "subjective* well-being" OR "environmental well- } \\
\text { being)) }\end{array}$ \\
\hline Scopus index & $\begin{array}{l}\text { TITLE-ABS-KEY = (("urban green spaces*“ OR "urban greenness" OR "urban vegetation" OR "urban parks") } \\
\text { and ("human well-being*" OR "quality of life*" OR "physical* well-being " OR "physical health" OR } \\
\text { "psychological* well-being" OR "psychological health" OR "mental* well-being " OR "mental stress" OR } \\
\text { "mental health" OR "social* well-being " OR "social cohesion" OR "subjective* well-being " OR "environmental } \\
\text { well-being)) }\end{array}$ \\
\hline PubMed & $\begin{array}{l}\text { (("urban green spaces*" OR "urban greenness" OR "green infrastructure" OR “urban vegetation" OR "urban } \\
\text { parks") and ("human well-being*" OR "physical* well-being" OR "physical health" OR "psychological* well- } \\
\text { being" OR "psychological health" OR "mental* well-being" OR "mental stress" OR "mental health" OR } \\
\text { "social* well-being" OR "social cohesion" OR "subjective* well-being" OR "life satisfaction")) }\end{array}$ \\
\hline
\end{tabular}

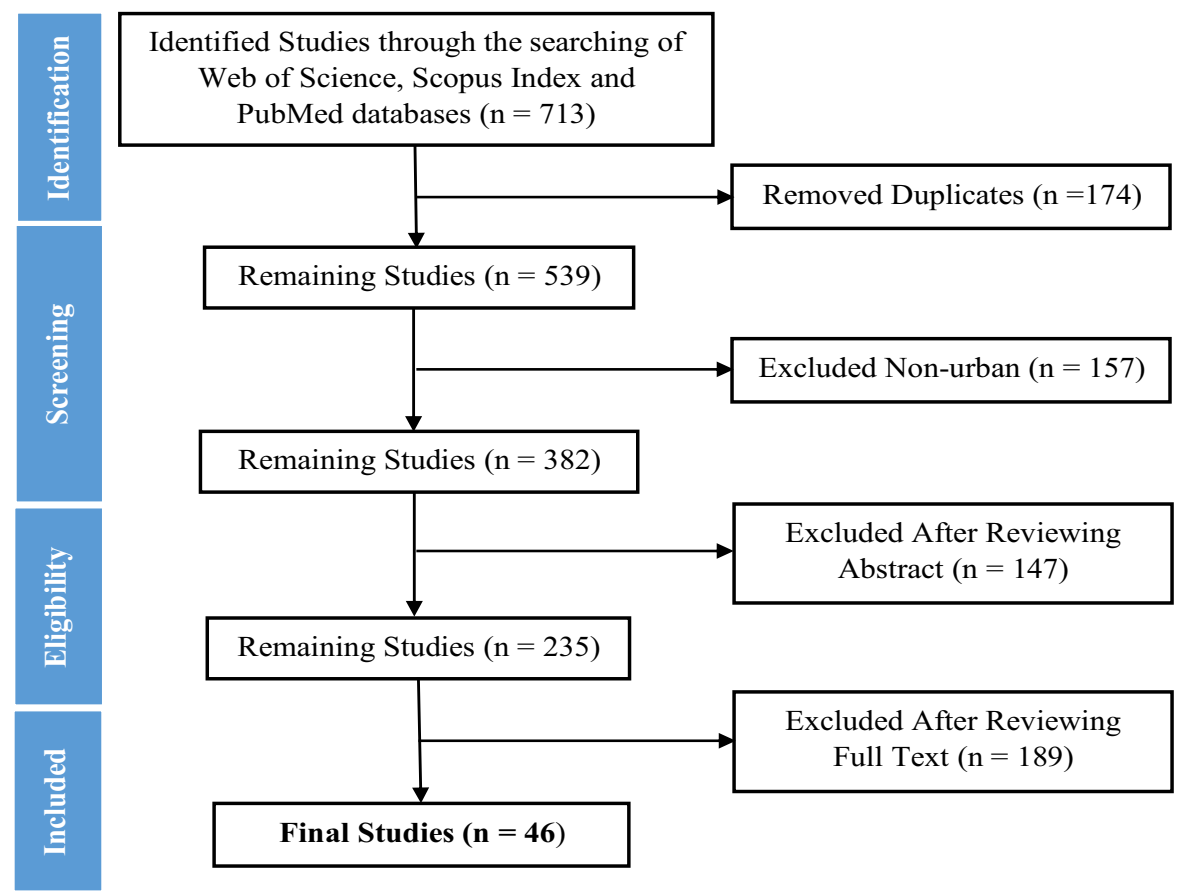

Fig. 1 Selection process of the studies for the review

\section{Data extraction}

Data extraction was performed in October 2020 on reviewing complete studies, including the abstract, conclusion, and future directions. After reviewing complete studies, themes and sub-themes were identified from the final selection of studies. The extracted data was stored in a table form according to the six sub-themes (physical well-being, psychological wellbeing, mental well-being, social well-being, subjective well-being, and environmental well-being) of the study. Therefore, the extracted data was organized under these sub-themes. 
Table 2 Detail of reviewed studies

\begin{tabular}{|c|c|c|c|c|c|c|}
\hline Sr.\# & Author (Year) & Study area & Citations & Target group & Methods & Findings \\
\hline 1 & Akpinar (2016) & $\begin{array}{l}\text { Aydin } \\
\text { (Turki) }\end{array}$ & 139 & 420 visitors & $\begin{array}{l}\text { Multivariate linear } \\
\text { regression }\end{array}$ & $\begin{array}{l}\text { Quality, access, and physical } \\
\text { activities enhance mental and } \\
\text { physical health }\end{array}$ \\
\hline 2 & $\begin{array}{l}\text { Ayala-Azcárraga } \\
\text { et al. (2019) }\end{array}$ & Mexico City & 46 & $\geq 18$ years old & $\begin{array}{l}\text { Nonparametric Kruskall- } \\
\text { Wallis test and } \\
\text { univariate }\end{array}$ & $\begin{array}{l}\text { Physical health and life } \\
\text { satisfaction is found in the } \\
\text { neighbourhood of parks }\end{array}$ \\
\hline 3 & Ma et al. (2019) & $\begin{array}{l}\text { Beijing } \\
\text { (China) }\end{array}$ & 26 & 1002 Residents & $\begin{array}{l}\text { Seemingly unrelated } \\
\text { regressions model }\end{array}$ & $\begin{array}{l}\text { Highest well-being found within } \\
1-5 \mathrm{~km} \text { whereas lowest over } \\
10 \mathrm{~km}\end{array}$ \\
\hline 4 & $\begin{array}{l}\text { Brindley et al. } \\
\text { (2019) }\end{array}$ & $\begin{array}{l}\text { Sheffield } \\
\text { (UK) }\end{array}$ & 28 & 1500 residents & $\begin{array}{l}\text { Spearman correlation and } \\
\text { negative binomial } \\
\text { regression }\end{array}$ & $\begin{array}{l}\text { UGSs quality is an essential } \\
\text { factor for the alleviation of } \\
\text { poor general health }\end{array}$ \\
\hline 5 & $\begin{array}{l}\text { Cameron et al. } \\
(2020)\end{array}$ & $\begin{array}{l}\text { Sheffield } \\
\text { (UK) }\end{array}$ & 19 & 259 visitors & $\begin{array}{l}\text { One-way ANOVA for } \\
\text { difference \& pearson } \\
\text { product-moment } \\
\text { correlation }\end{array}$ & $\begin{array}{l}\text { Biodiversity in UGS has strong } \\
\text { relations with positive } \\
\text { emotions }\end{array}$ \\
\hline 6 & $\begin{array}{l}\text { Chang et al. } \\
\text { (2020) }\end{array}$ & Taiwan & 27 & 151 visitors & $\begin{array}{l}\text { Pearson product-moment } \\
\text { correlations coefficient }\end{array}$ & $\begin{array}{l}\text { Ecological richness and } \\
\text { diversity in UGS encouraged } \\
\text { by the visitors }\end{array}$ \\
\hline 7 & $\begin{array}{l}\text { Dadvand et al. } \\
\text { (2019) }\end{array}$ & Iran & 28 & $\begin{array}{l}10,856 \\
\text { adolescents }\end{array}$ & $\begin{array}{l}\text { Logistic mixed-effects } \\
\text { models with self- } \\
\text { satisfaction }\end{array}$ & $\begin{array}{l}\text { Time spends in UGSs enhanced } \\
\text { subjective, social, and mental } \\
\text { well-being }\end{array}$ \\
\hline 8 & $\begin{array}{l}\text { Dong and } \\
\text { Hauschild } \\
(2017)\end{array}$ & $\begin{array}{l}\text { Beijing } \\
\text { (China) }\end{array}$ & 58 & 712 residents & $\begin{array}{l}\text { Principle component } \\
\text { analysis, \& Hierarchical } \\
\text { linear modeling, }\end{array}$ & $\begin{array}{l}\text { Proximity to UGSs is found } \\
\text { significant for subjective and } \\
\text { mental well-being }\end{array}$ \\
\hline 9 & $\begin{array}{l}\text { Duan et al. } \\
\text { (2018) }\end{array}$ & $\begin{array}{l}\text { Guangzhou } \\
\text { (China) }\end{array}$ & 16 & 396 visitors & $\begin{array}{l}\text { Non-parametric Kruskal } \\
\text { Wallis test, binary } \\
\text { logistic regression } \\
\text { model }\end{array}$ & $\begin{array}{l}\text { UGSs mitigate environmental } \\
\text { risks for humans by cooling } \\
\text { and filtering the air }\end{array}$ \\
\hline 10 & $\begin{array}{l}\text { Enssle and } \\
\text { Kabisch (2020) }\end{array}$ & $\begin{array}{l}\text { Berlin } \\
\text { (Germany) }\end{array}$ & 31 & $\begin{array}{l}506 \text { aged } \\
\text { visitors } \\
(50+\text { years })\end{array}$ & $\begin{array}{l}\text { Non-parametric Kruskal- } \\
\text { Wallis test, Pearson chi- } \\
\text { squared tests }\end{array}$ & $\begin{array}{l}\text { Urban parks improve social } \\
\text { interaction and human health } \\
\text { in neighborhood }\end{array}$ \\
\hline 11 & $\begin{array}{l}\text { Gascon et al. } \\
\text { (2018) }\end{array}$ & $\begin{array}{l}\text { Barcelona } \\
\text { (Spain) }\end{array}$ & 93 & 958 adults & $\begin{array}{l}\text { Logistic regression } \\
\text { models }\end{array}$ & $\begin{array}{l}\text { UGSs improve mental health by } \\
\text { reducing air pollution and } \\
\text { noise }\end{array}$ \\
\hline 12 & $\begin{array}{l}\text { Georgi and } \\
\text { Dimitriou } \\
(2010)\end{array}$ & $\begin{array}{l}\text { Chania } \\
\text { (Greece) }\end{array}$ & 238 & $\begin{array}{l}52,000 \\
\text { residents }\end{array}$ & $\begin{array}{l}\text { SKYMASTER, Model } \\
\text { SM-28, One way } \\
\text { ANOVA and t-Test }\end{array}$ & $\begin{array}{l}\text { UGSs increase life satisfaction, } \\
\text { improve city environment \& } \\
\text { thermal comfort }\end{array}$ \\
\hline 13 & $\begin{array}{l}\text { Gubbels et al. } \\
\text { (2016) }\end{array}$ & Netherland & 49 & $\begin{array}{l}401 \text { adolescents } \\
\& 454 \text { adults }\end{array}$ & $\begin{array}{l}\text { Multivariate linear } \\
\text { regression models }\end{array}$ & $\begin{array}{l}\text { Urban greenery has positive } \\
\text { effects on human health and } \\
\text { behaviour leisure time }\end{array}$ \\
\hline 14 & $\begin{array}{l}\text { Helbich et al., } \\
\text { 2018) }\end{array}$ & Netherland & 39 & $\begin{array}{l}403 \\
\text { municipalities }\end{array}$ & $\begin{array}{l}\text { Spearman's rank } \\
\text { correlation coefficients }\end{array}$ & $\begin{array}{l}\text { Green space is a central health } \\
\text { and community asset with a } \\
\text { minimum of } 28 \%\end{array}$ \\
\hline 15 & Holt et al. (2019) & $\begin{array}{l}\text { United } \\
\text { States }\end{array}$ & 32 & 207 Students & $\begin{array}{l}\text { Chi-squared tests \& } \\
\text { logistic regression } \\
\text { model }\end{array}$ & $\begin{array}{l}\text { Regular interaction with UGSs } \\
\text { reported higher QoL, better } \\
\text { mood, and lower stress }\end{array}$ \\
\hline 16 & $\begin{array}{l}\text { Hong et al. } \\
\text { (2019) }\end{array}$ & $\begin{array}{r}\text { Daejeon } \\
\text { (South } \\
\text { Korea) }\end{array}$ & 8 & 400 residents & SEM models \& ANOVA & $\begin{array}{l}\text { Regular visits \& maximum time } \\
\text { spend in UGSs increase } \\
\text { subjective well-being }\end{array}$ \\
\hline
\end{tabular}


Table 2 continued

\begin{tabular}{|c|c|c|c|c|c|c|}
\hline Sr.\# & Author (Year) & Study area & Citations & Target group & Methods & Findings \\
\hline 17 & $\begin{array}{l}\text { Houlden et al. } \\
\text { (2019) }\end{array}$ & $\begin{array}{l}\text { London } \\
\text { (UK) }\end{array}$ & 22 & $\begin{array}{l}15,000 \\
\quad \text { residents }\end{array}$ & $\begin{array}{l}\text { OLS regression \& } \\
\text { geographically } \\
\text { weighted regression } \\
\text { model }\end{array}$ & $\begin{array}{l}\text { Mental well-being increased } \\
\text { with the decreasing distance } \\
\text { from green spaces }\end{array}$ \\
\hline 18 & $\begin{array}{l}\text { Koprowska et al. } \\
\text { (2018) }\end{array}$ & $\begin{array}{l}\text { Lodz } \\
\quad \text { (Poland) }\end{array}$ & 31 & $\begin{array}{l}105,960 \\
\text { residents }\end{array}$ & Spatial error probit model & $\begin{array}{l}\text { The direct effect of UGSs found } \\
\text { positive at large extent to } \\
\text { reduce noise pollution }\end{array}$ \\
\hline 19 & $\begin{array}{l}\text { Kothencz et al. } \\
\text { (2017) }\end{array}$ & $\begin{array}{l}\text { Szeged } \\
\text { (Hungary) }\end{array}$ & 60 & 227 visitors & $\begin{array}{l}\text { Ordinal logistic } \\
\text { regression model }\end{array}$ & $\begin{array}{l}\text { Recreation capacity in UGSs } \\
\text { increases life satisfaction } \\
\text { amongst the visitors }\end{array}$ \\
\hline 20 & $\begin{array}{l}\text { Larson et al. } \\
\text { (2016) }\end{array}$ & $\begin{array}{l}\text { United } \\
\text { States }\end{array}$ & 183 & $\begin{array}{l}160,000 \\
\text { residents }\end{array}$ & OLS regression model & $\begin{array}{l}\text { Strong positive relations found } \\
\text { between UGSs and human } \\
\text { physical well-being }\end{array}$ \\
\hline 21 & $\begin{array}{l}\text { Lee and Lee } \\
\text { (2019) }\end{array}$ & South Korea & 22 & $\begin{array}{l}11,408 \text { aged } \\
\text { residents }\end{array}$ & $\begin{array}{l}\text { Chi-squared Test \& } \\
\text { binary logistic } \\
\text { regression }\end{array}$ & $\begin{array}{l}\text { UGSs within the community is } \\
\text { an essential element for mental } \\
\text { health }\end{array}$ \\
\hline 22 & $\begin{array}{l}\text { Mears et al. } \\
\text { (2020) }\end{array}$ & $\begin{array}{l}\text { Sheffield } \\
\text { (UK) }\end{array}$ & 12 & 293 residents & $\begin{array}{l}\text { Negative binomial } \\
\text { regression \& Spearman } \\
\text { correlation }\end{array}$ & $\begin{array}{l}\text { UGSs has hostile relations with } \\
\text { poor health \& cleanliness } \\
\text { decreases stress }\end{array}$ \\
\hline 23 & $\begin{array}{l}\text { Meyer- } \\
\text { Grandbastien } \\
\text { et al. (2020) }\end{array}$ & $\begin{array}{l}\text { Rennes } \\
\quad \text { (France) }\end{array}$ & 7 & 390 visitors & $\begin{array}{l}\text { Pearson correlation } \\
\text { analyses }\end{array}$ & $\begin{array}{l}\text { Mixed landscapes in UGSs are } \\
\text { merely helpful for } \\
\text { psychological restoration }\end{array}$ \\
\hline 24 & $\begin{array}{l}\text { Mavoa et al. } \\
\text { (2019) }\end{array}$ & $\begin{array}{l}\text { Melbourne } \\
\text { (Australia) }\end{array}$ & 26 & 4912 adults & $\begin{array}{l}\text { Pearson correlations \& } \\
\text { leaner regression model }\end{array}$ & $\begin{array}{l}\text { The higher association found } \\
\text { between green spaces and } \\
\text { subjective well-being }\end{array}$ \\
\hline 25 & $\begin{array}{l}\text { Nath et al. } \\
\text { (2018) }\end{array}$ & $\begin{array}{l}\text { Kuala } \\
\text { Lumpur } \\
\text { (Malaysia) }\end{array}$ & 33 & 310 visitors & $\begin{array}{l}\text { Statistical ratio } \\
\text { comparison \& chi- } \\
\text { squared test }\end{array}$ & $\begin{array}{l}\text { Parks had a positive influence on } \\
\text { mental, physical, and overall } \\
\text { well-being }\end{array}$ \\
\hline 26 & $\begin{array}{l}\text { Navarrete- } \\
\text { Hernandez and } \\
\text { Laffan (2019) }\end{array}$ & $\begin{array}{l}\text { Valparaiso } \\
\text { (Chile) }\end{array}$ & 16 & 240 visitors & $\begin{array}{l}\text { Used random intercept } \\
\text { models \& regression } \\
\text { coefficients analyses }\end{array}$ & $\begin{array}{l}\text { Street-level greenery has } \\
\text { positive effects on feelings, } \\
\text { happiness \& stress reduction }\end{array}$ \\
\hline 27 & $\begin{array}{l}\text { Nutsford et al. } \\
\text { (2013) }\end{array}$ & $\begin{array}{l}\text { Auckland } \\
\text { (New } \\
\text { Zealand) }\end{array}$ & 320 & 3149 area units & $\begin{array}{l}\text { Negative binomial } \\
\text { regression model }\end{array}$ & $\begin{array}{l}\text { Access and active participation } \\
\text { in UGSs decrease } \\
\text { anxiety/mood disorder issues }\end{array}$ \\
\hline 28 & $\begin{array}{l}\text { Paul and } \\
\text { Nagendra } \\
(2017)\end{array}$ & Delhi (India) & 51 & 123 visitors & ANOVA and t-test & $\begin{array}{l}\text { UGSs reduce human } \\
\text { psychological, social, and } \\
\text { environmental issues }\end{array}$ \\
\hline 29 & $\begin{array}{l}\text { Reis andLopes } \\
\text { (2019) }\end{array}$ & $\begin{array}{l}\text { Lisbon } \\
\text { (Portugal) }\end{array}$ & 17 & Not specific & $\begin{array}{l}\text { Simple leaner regression } \\
\text { model }\end{array}$ & $\begin{array}{l}\text { An area of } 50 \mathrm{~m}^{2} \text { covered by } \\
\text { vegetation can cool the air by } \\
1^{\circ} \mathrm{C}\end{array}$ \\
\hline 30 & $\begin{array}{l}\text { Rey Gozalo } \\
\text { et al. (2018) }\end{array}$ & $\begin{array}{l}\text { Cáceres } \\
\text { (Spain) }\end{array}$ & 65 & 182 residents & $\begin{array}{l}\text { Non-parametric Mann- } \\
\text { Whitney test, bivariate } \\
\text { \& partial correlation }\end{array}$ & $\begin{array}{l}\text { The highest relationships found } \\
\text { between UGSs and overall } \\
\text { human well-being }\end{array}$ \\
\hline 31 & Roe et al. (2016) & $\begin{array}{l}\text { England } \\
\text { (UK) }\end{array}$ & 70 & 480 residents & $\begin{array}{l}\text { Non-parametric test \& } \\
\text { regression model }\end{array}$ & $\begin{array}{l}\text { The interaction with UGSs } \\
\text { determine general health } \\
\text { benefits }\end{array}$ \\
\hline 32 & $\begin{array}{l}\text { Schebella et al. } \\
\text { (2019) }\end{array}$ & $\begin{array}{l}\text { S. Australia } \\
\text { (Australia) }\end{array}$ & 25 & 840 residents & $\begin{array}{l}\text { Regression model, } \\
\text { ANOVA, correlations }\end{array}$ & $\begin{array}{l}\text { Biodiversity in UGSs is strongly } \\
\text { associated with psychological } \\
\text { well-being }\end{array}$ \\
\hline 33 & $\begin{array}{l}\text { Scopelliti et al. } \\
\text { (2016) }\end{array}$ & $\begin{array}{l}\text { Bogotá } \\
\text { (Colombia) }\end{array}$ & 91 & 398 visitors & $\begin{array}{l}\text { Bonferroni correction for } \\
\text { comparison \& bivariate } \\
\text { correlations }\end{array}$ & $\begin{array}{l}\text { High Physical \& psychological } \\
\text { benefits received by the } \\
\text { middle-income group }\end{array}$ \\
\hline
\end{tabular}


Table 2 continued

\begin{tabular}{|c|c|c|c|c|c|c|}
\hline Sr.\# & Author (Year) & Study area & Citations & Target group & Methods & Findings \\
\hline 34 & $\begin{array}{l}\text { Selmi et al. } \\
\text { (2016) }\end{array}$ & $\begin{array}{l}\text { Strasbourg } \\
\text { (France) }\end{array}$ & 245 & Not specific & $\begin{array}{l}\text { i-Tree Eco-model was } \\
\text { used to calculate } \\
\text { vegetation benefits }\end{array}$ & $\begin{array}{l}\text { Large trees are significantly } \\
\text { associated with the vital } \\
\text { removal of air pollution }\end{array}$ \\
\hline 35 & $\begin{array}{l}\text { Southon et al. } \\
\text { (2018) }\end{array}$ & $\begin{array}{l}\text { Bedford and } \\
\text { Luton } \\
\text { (UK) }\end{array}$ & 73 & 360 visitors & $\begin{array}{l}\text { Chi-squared test \& linear } \\
\text { mixed-effects models }\end{array}$ & $\begin{array}{l}\text { Richness of tree species is } \\
\text { strongly associated with } \\
\text { psychological well-being }\end{array}$ \\
\hline 36 & $\begin{array}{l}\text { Taylor et al. } \\
\text { (2018) }\end{array}$ & $\begin{array}{l}\text { Australia \& } \\
\text { NZ (Four } \\
\text { cities) }\end{array}$ & 33 & 1819 residents & $\begin{array}{l}\text { NDVI, \& leaner } \\
\text { regression analyses }\end{array}$ & $\begin{array}{l}\text { Proximity \& time spend in green } \\
\text { spaces are closely associated } \\
\text { with well-being }\end{array}$ \\
\hline 37 & $\begin{array}{l}\text { Thompson } \\
\text { (2016) }\end{array}$ & $\begin{array}{l}\text { Scotland } \\
\text { (UK) }\end{array}$ & 131 & 406 adults & $\begin{array}{l}\text { Regression, chi-squared } \\
\text { automatic interaction } \\
\text { detection }\end{array}$ & $\begin{array}{l}\text { Access to green spaces enhanced } \\
\text { human mental well-being and } \\
\text { general health }\end{array}$ \\
\hline 38 & Tsai et al. (2018) & $\begin{array}{l}\text { United } \\
\text { States } \\
\text { (various } \\
\text { cities) }\end{array}$ & 41 & 276 residents & $\begin{array}{l}\text { One-way analysis of } \\
\text { variance \& stepwise } \\
\text { logistic regression }\end{array}$ & $\begin{array}{l}\text { Shrubland has positive effects in } \\
\text { the reduction of frequent } \\
\text { mental distress }\end{array}$ \\
\hline 39 & $\begin{array}{l}\text { Vieira et al. } \\
\text { (2018) }\end{array}$ & $\begin{array}{l}\text { Almada } \\
\text { (Portugal) }\end{array}$ & 100 & Not specific & $\begin{array}{l}\text { Non-metric } \\
\text { multidimensional } \\
\text { scaling, one way } \\
\text { ANOVA \& NDVI }\end{array}$ & $\begin{array}{l}\text { UGSs are an essential nature- } \\
\text { based solution to UHI effects } \\
\text { and air pollution }\end{array}$ \\
\hline 40 & $\begin{array}{l}\text { Vujcic et al. } \\
\text { (2019) }\end{array}$ & $\begin{array}{l}\text { Belgrade } \\
\quad \text { (Serbia) }\end{array}$ & 35 & $\begin{array}{l}181,231 \\
\quad \text { residents }\end{array}$ & $\begin{array}{l}\text { t-Test, multiple } \\
\text { regression \& Pearson } \\
\text { correlational }\end{array}$ & $\begin{array}{l}\text { The higher green areas and their } \\
\text { quality led to greater health } \\
\text { outcomes }\end{array}$ \\
\hline 41 & $\begin{array}{l}\text { Wang et al. } \\
\text { (2019a, 2019b) }\end{array}$ & $\begin{array}{l}\text { Jiangsu } \\
\text { (China) }\end{array}$ & 40 & 300 residents & $\begin{array}{l}\text { Multifactor ANOVA \& } \\
\text { leaner regression }\end{array}$ & $\begin{array}{l}\text { More trees, flowers, clear water } \\
\text { attract visitors and improve } \\
\text { mental health }\end{array}$ \\
\hline 42 & $\begin{array}{l}\text { Wang et al. } \\
\text { (2019a, 2019b) }\end{array}$ & $\begin{array}{l}\text { Guangzhou } \\
\text { (China) }\end{array}$ & 59 & 1029 adults & $\begin{array}{l}\text { NDVI, non-parametric } \\
\text { Spearman correlation, } \\
\text { linear regression } \\
\text { models }\end{array}$ & $\begin{array}{l}\text { Green spaces enhanced mental } \\
\text { well-being through Physical } \\
\text { activities and Social } \\
\text { Interaction }\end{array}$ \\
\hline 43 & $\begin{array}{l}\text { White et al. } \\
\text { (2017) }\end{array}$ & $\begin{array}{l}\text { England } \\
\text { (UK) }\end{array}$ & 108 & 7272 residents & $\begin{array}{l}\text { Unadjusted binary } \\
\text { logistic regression }\end{array}$ & $\begin{array}{l}\text { visiting green spaces even once } \\
\text { a week is essential for } \\
\text { eudaimonic well-being }\end{array}$ \\
\hline 44 & $\begin{array}{l}\text { White et al. } \\
\text { (2013) }\end{array}$ & $\begin{array}{l}\text { England } \\
\text { (UK) }\end{array}$ & 737 & $\begin{array}{l}10,000 \\
\text { residents }\end{array}$ & $\begin{array}{l}\text { Fixed-effects regression } \\
\text { approach }\end{array}$ & $\begin{array}{l}\text { More availability of UGSs lower } \\
\text { mental distress and improve } \\
\text { subjective WB }\end{array}$ \\
\hline 45 & $\begin{array}{l}\text { Wood et al. } \\
\text { (2017) }\end{array}$ & $\begin{array}{l}\text { Perth } \\
\text { (Australia) }\end{array}$ & 182 & 492 residents & $\begin{array}{l}\text { Public open space } \\
\text { desktop auditing tool } \\
\text { (POSDAT) \& linear } \\
\text { regression }\end{array}$ & $\begin{array}{l}\text { Parks in neighbourhoods within } \\
\text { walking distance is significant } \\
\text { for mental health }\end{array}$ \\
\hline 46 & $\begin{array}{l}\text { Zhang and Tan } \\
\text { (2019) }\end{array}$ & Singapore & 20 & 1000 residents & $\begin{array}{l}\text { Chi-square, t-test, binary } \\
\text { logistic regression }\end{array}$ & $\begin{array}{l}\text { Canopy cover showed strong } \\
\text { associations with mental } \\
\text { health at most of the scales }\end{array}$ \\
\hline
\end{tabular}

UGSs urban green spaces, $Q o L$ quality of life, WB well-being, UHI urban heat Island

\section{Organization of data}

The extracted data was organized in Table 2, where the author and year of publication were specified in column one, the study area in column two, received citations till May 2021, in column three, target group (population) in column four, applied methods in column five, and findings were organized in the 


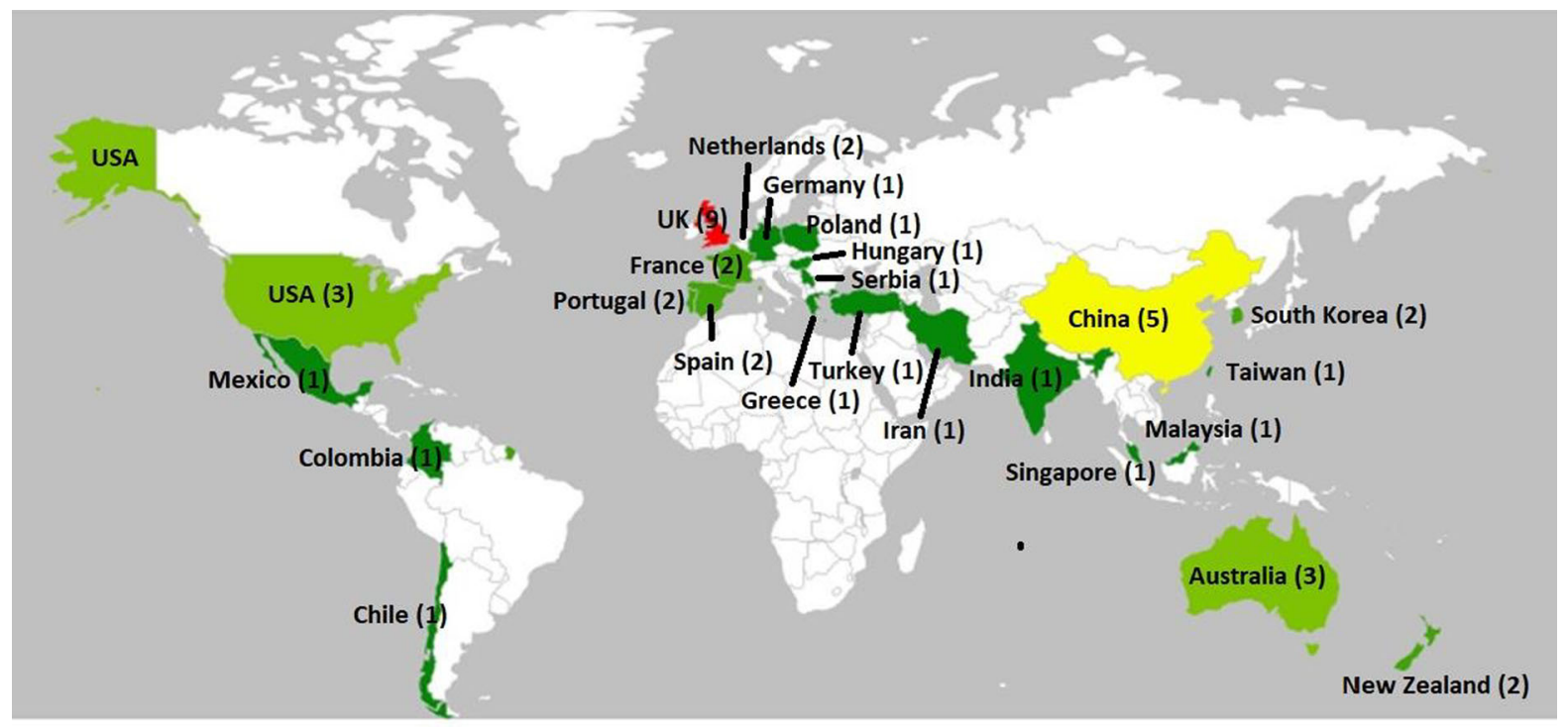

Fig. 2 Spatial distribution of reviewed studies

last column. All the above said parts of each paper were arranged shortly, reflecting all main elements of the papers. Consequently, the detail of each paper with location on the world map was shown (Fig. 2).

\section{Results}

A summary result of the reviewed studies is given in Table 2.

The role of urban green spaces is recognized mainly by healthy human life and city sustainability in most of the studies. Scholars have assessed urban green spaces with different domains in different studies. The review analyzed various researchers' achievements in identifying urban green spaces services for social life events, especially in urban, the busiest, and stressful lifestyles. All the reviewed studies found the following characteristics:

\section{Study areas}

The study found that reviewed studies covered four continents; Asia, Europe, North America, and South America. In Asia, five studies belong to China (Ben Ma et al., 2019; Dong \& Qin 2017; Duan et al., 2018; Ronghua Wang et al., 2019a, 2019b; Ruoyu Wang et al., 2019a, 2019b), two from South Korea (Hong et al., 2019; Lee \& Lee, 2019), and one of each study belongs to Turkey (Akpinar A., 2016), Taiwan (Chang et al., 2020), Iran (Dadvand et al., 2019), Malaysia (Nath et al., 2018), India (Paul \& Nagendra, 2017), Singapore (Zhang \& Tan, 2019). In Europe, nine studies belong to United Kingdom (Brindley et al., 2019; Cameron et al., 2020; Houlden et al., 2019; Mears et al., 2020; Roe et al., 2016; Southon et al., 2018; Thompson et al., 2016; White et al., 2013, 2017), two of each study belong to Spain (Gascon et al., 2018; Rey Gozalo et al., 2018), Netherlands (Gubbels et al., 2016; Helbich et al., 2018), France (Meyer-Grandbastien et al., 2020; Selmi et al., 2016), Portugal (Reis \& Lopes, 2019; Vieira et al., 2018), one of each study belongs to Germany (Enssle \& Kabisch, 2020), Greece (Georgi \& Dimitriou, 2010), Hungry (Kothencz et al., 2017), Poland (Koprowska et al., 2018), Serbia (Vujcic et al., 2019). In North America, three studies belong to the USA (Holt et al., 2019; Larson et al., 2016; Tsai et al., 2018) and one from Mexico (Ayala-Azcárraga et al., 2019). In South America, one study belongs to Colombia (Scopelliti et al., 2016) and Chile (Navarrete \& Laffan, 2019). In the Australian continent, three studies belong to Australia (Mavoa et al., 2019; Schebella et al., 2019; Wood et al., 2017) and two from New Zealand (Nutsford et al., 2013; Taylor et al., 2018). 
Target group (population)

The reviewed studies observed almost all population groups above 18 years old, but some studies targeted a specific group. For instance, Gubbels et al. (2016) targeted adolescents and adults in Netherland, Lee and Lee (2019) observed elders in South Korea, Holt et al. (2019) selected university students in the USA, and Wang et al., (2019a, 2019b) observed adults only in China. Similarly, most of the reviewed studies belong to developed countries like the UK, USA, Spain, France, Netherlands, Germany, Singapore, New Zealand, and high ranked developing countries like China, Turkey, Taiwan, South Korea, and Malaysia.

\section{Chosen methodologies}

In data collection methods, $89 \%$ of the study is based on primary data (cross-sectional studies), 9\% of studies used secondary, whereas only $2 \%$ of the study is based on experimental data (empirical studies). Most of the studies used Landsat images and NDVI to identify the study area and vegetation configuration in the data analysis section, whereas Selmi et al. (2016) used i-Tree Eco-model to quantify vegetation services for the environment. For statistical analysis, the studies mostly used the One-way ANOVA Test for analyzing the significance level of independent variables and the Chi-squared test for associations of categorical variables. In the correlation section, most of the studies used Pearson Product-moment Correlation to test the superficial relationships of variables, whereas Binary Logistic Regression and Linear Regression Model for cause and effects variables. Detail of each study is given in Table 2 .

\section{Mediations}

In the reviewed literature, most studies recommended urban green spaces as a lifeline for large cities worldwide. The availability of green spaces essential but not as such as through mediation. Green spaces improve human physical health and well-being by providing space for exercise, jogging, walking, cycling, and other recreational activities. So, human physical well-being and fitness can be obtained by using mediators (exercise, jogging, cycling, and other recreational activities). Likewise, easy access to urban green spaces is one of the significant mediators for human well-being. Urban green spaces improve human mental and psychological health in the old age population by removing social isolation. So, social interaction is an essential mediator for human mental and psychological well-being. The reviewed literature depicted that cleanliness and a calm environment also improve the benefits of green spaces. In youth, recreational activities and maximum interaction enhance the mental approach and academic performance. To sum up, the reviewed studies collectively highlighted the full benefits of urban green spaces that could be obtained through mediations of easy access, daily interaction, social cohesion, physical exercise, jogging, cycling, walking, and recreational and cultural activities.

\section{Findings}

The reviewed studies found under the following six sub-themes of human well-being:

\section{Physical well-being}

Physical well-being is a state of the body with the absence of diseases, but also it is a balanced state of the human body with its lifestyle, having choices to ensure health (Physical Well-Being, n.d.). Urban green spaces have been observed in various ways to benefit human well-being through physical activities. A positive relationship has been shown in a cross-sectional study conducted in England (UK) to explore relationships between a natural environment and human well-being. The study concluded that urban green spaces positively interact with human health and save the human body from different diseases. Even a weekly visit to green spaces has positive effects on the human body (White et al., 2017). In Guangzhou city of China, a study explored the residents' perceptions about environmental risks and green infrastructure. The study concluded that low air quality and high temperatures negatively affect human health and caused dysphoria and anxiety.

In contrast, green infrastructure provides services to reduce the temperature and clean the air for breathing to enhance human health (Duan et al., 2018). Human health is closely related to the natural environment, and urban green spaces are a source of the natural environment in cities that actively promote and maintain humans' physical fitness and well-being 
(Holt et al., 2019; Nath et al., 2018). The frequent visit and maximum time consumption in the green environment resulted positively for human physical health in Daejeon (South Korea), and these results have been obtained during a cross-sectional study based on 400 respondents (Hong et al., 2019). Urban green spaces offer numerous benefits for human well-being in various forms, and all those forms are interconnected to physical health. During research in London (UK), it has been assessed that the proximity of green spaces provides maximum benefits to humans, and $300 \mathrm{~m}$ is an ideal range of access suggested for taking full benefits. The city planners and policymakers suggested green spaces within an accessible range to maintain human health and well-being (Holt et al., 2019; Kothencz et al., 2017). The activities related to running, walking, and relaxing are negatively associated with health problems, stress, and sedentary lifestyle issues (Rey Gozalo et al., 2018).

The impacts of urban green spaces on physical health and well-being vary in different ethnic groups in England. It has been assessed that recreational policy is needed within urban green parks to improve the general health and inequalities amongst deprived communities in the UK (Roe et al., 2016). The high density of green spaces increased the potential of physical well-being in urban residents with other significant health outcomes. Recreational and related activities like walking, jogging, and running is negatively associated with self-reported nerve problems among Almada's residents (Portugal). It has been recommended that the frequent visit of urban parks reduces human nervous problems like medication (Vujcic et al., 2019). Frequent usage of green landscapes for physical events decreases health issues in the human body and enhances physical fitness (Thompson, 2016). Properly managed and clean green spaces increase their capability to facilitate the urban environment and human health. The structure, accessibility, quantity, and quality of urban green spaces are vital for their potential and city environment. In Sheffield (UK), a study concluded that cleanliness has strong positive relations with general health. The study resulted that poor human health was reported where the green spaces were not properly managed and cleaned (Brindley et al., 2019). A study was directed to assess Beijing's level of satisfaction with urban green spaces for human well-being. The results showed that the people who live within $1-5 \mathrm{~km}$ zone and regular visitors of public green spaces are found more physically and mentally fit and healthier than 5-10 zone residents. The study also concluded that human physical well-being is positively associated with age, income, education, marital status, residential area, and career status (Akpinar, 2016; Ma et al., 2019).

\section{Psychological well-being}

Psychological well-being is a positive functioning of self-esteem, including a sense of mastery and personal growth at inter and intraindividual levels. In some studies, psychological well-being stated positive feelings, happiness, and life satisfaction (What Is Psychological Well-being?|Robertson Cooper, n.d.). Human psychology and its related studies are continually known as complex tasks for the researcher, and human psychological well-being relations with urban green spaces are one of them. The impacts of green spaces on human psychological health and well-being differ with green spaces' structure and quality. Social psychological issues cannot be handled with nature entirely, but they can be reduced by increasing connectivity with a natural environment and green landscapes. A study has concluded that meadows have limited effects on human psychology, but the richness of trees strongly influences psychological well-being (Southon et al., 2018). Several human benefits are closely associated with nature, and the closeness of green spaces from home or workplace has positive effects. Urban life creates stress on residents due to its busy and sedentary lifestyle, but when they visit green spaces or natural green landscapes and spend maximum time, they feel well and relaxed. In this way, visitors release stress and boost up their psychological health. According to a study on four different cities, Auckland, Willington (New Zealand), Melbourne, and Sydney (Australia), the effects of urban green spaces were different due to variations in types and richness of biodiversity. Psychological well-being was found more positively associated with green spaces in Sydney, resulting in $P<0.001$. In this study, the scholar suggested a more intensive investigation (Taylor et al., 2018). A natural environment found enrich with positive impacts on human psychology. Interaction with nature keeps to maintain and strengthen human psychological well-being. The connectivity with green landscapes decreases psychological issues. It has been recommended that 
greenness in urban areas is an essential part of urban life and human psychological restoration (White et al., 2017).

The characteristics of urban green spaces are also decisive for human well-being. According to the study of Ronghua Wang on Hangzhou city (China), the characteristics of urban green spaces positively affect human aesthetic values and stress recovery. The study investigated urban green spaces as a source of enjoyment and a platform for relaxing and recovering from mental fatigue. The study concluded that green spaces with a richness of trees, clean water, and bright flower attract people and assist in mental stress recovery. Therefore, green parks with numerous trees and flowers are recommended by studying mental stress recovery and aesthetic preference (Wang et al., 2019a, 2019b). 'Urban green spaces and their richness may negatively affect human psychological and physical well-being' hypothesis was a study conducted by Chang et al. (2020) in Taiwan. The study found that the richness of biodiversity did not negatively affect the residents. Therefore, according to the study findings, biodiversity's richness does not negatively affect human psychological and physical wellbeing (Chang et al., 2020). The role of urban green spaces in highly populated areas is found significant for psychological and physical well-being, but the level of significance differs from different income groups (Scopelliti et al., 2016). Furthermore, urban green spaces promote social interaction, which helps to enhance psychological well-being (Jennings \& Bamkole, 2019).

The restoration of human psychology is positively relating to the heterogeneity of green landscapes. Urban green spaces in human psychological wellbeing may vary based on different species in a green space. In Rennes (France), it has been observed that the awareness about the composition and configuration of a green landscape is positively associated with psychological restoration. Therefore, composition and configuration heterogeneity in green spaces enhance human psychological well-being and promote environmental and social well-being (Meyer-Grandbastien et al., 2020). Naturalness, biodiversity, and tree canopy are closely associated with human well-being. The relationships between naturalness and biodiversity may be weak, but the vegetation cover has a strong relationship with human psychological well-being. The prosperity of urban green spaces differs from park to park. The links of natural parks with stress reduction and mood improvement are strong but weak with pocket parks (Schebella et al., 2019). A study was conducted on four different well-maintained public parks of Delhi to investigate human well-being benefits. The study interviewed 250 visitors, and $87 \%$ responded favouring environmental well-being, $68 \%$ for human psychological well-being, and $45 \%$ for social, recreational benefits. Delhi public parks visitors' perception favours human psychological and environmental well-being as well as social and recreational activities (Paul \& Nagendra, 2017).

\section{Mental well-being}

Mental well-being is a state in which humans can; understand their potential, work productively, manage the stress of life, and participate in society usually. So, it cannot be known only as an absence of mental illness (World Health Organization, Promotion of Mental Well-Being, n.d.). The existence of green spaces for human health is well documented and recognized. The neighbourhood of greenness improves the human mental state. In Barcelona (Spain), a study was directed to explore the long-term exposure to the effects of green and blue spaces on depression and anxiety with the mediation of air pollution. The study analyzed a negative association of depression and anxiety with urban green spaces. The study concluded that green spaces improve human mental health, reduce anxiety and release human depression during interaction of green spaces, clean the air, reduce noise, provide spaces for physical activities and social interaction (Gascon et al., 2018; Nutsford et al., 2013). In Netherland, a cross-sectional study is recommended as a precious asset to urban green spaces for society because of the multi-beneficial landscape. According to the study conclusion, green spaces contribute actively as an antidepressant and enhance human mental health if green spaces' ratio exists a minimum of $28 \%$, but the highest benefits can be obtained with more than 79\% (Helbich et al., 2018). Green spaces are a significant source of mental wellbeing through a reduction of mental stress and depression. The role of urban green spaces has been analyzed as a buffer zone for human stress and anxiety. According to a study in the United States on undergraduate students who kept in touch with green spaces (open and woodland) were found happy and 
relaxed than others. The students who visited green spaces even last week were satisfied with their life and feeling well. The study concluded that the restoration of passive green spaces in universities increased students' health and life satisfaction (Holt et al., 2019).

The importance of urban green spaces can identify from a study conducted in Daejeon (South Korea). The study analyzed the impacts of frequent visits to green spaces and time spends on residents' life. The results showed positive relations between urban green spaces and human health and mental well-being (Hong et al., 2019). Urban green landscapes are well documented for mental well-being. Even in well-managed cities in the developed world, the role of green spaces is well recognized. Nowadays, everyone admits the significance of green spaces, but urban green spaces within the accessible range are an issue now. A longitudinal study was conducted in London (UK) based on 2012-2015 data. According to the results, green spaces within a $300 \mathrm{~m}$ radius are essential for every resident to keep them physically and mentally healthy. This radius is suggested ideal for a city planner and policymakers. The study concluded that the full benefits of urban green spaces for human health and mental growth are hidden in $300 \mathrm{~m}$ range and frequent visits (Houlden et al., 2019). The significance of green spaces within an accessible range provides full benefits. However, another aspect of urban green spaces benefits highlighted by Dadvan et al. (2019), and he recommended that a long time spends of adolescents (10-18 years old) in green spaces significantly associated with mental growth and enhance human mental performance (Dadvand et al., 2019). Outdoor regular activities and park visits positively correlate with human mental well-being (Dong \& Hauschild, 2017; Vujcic et al., 2019). Urban vegetation, even at the street level, provided positive effects on human well-being (Ma et al., 2019). Physical activities, social cohesion, noise, and air quality have been considered mediators for mental well-being in Guangzhou (China), which ultimately promotes human physical health (Wang et al., 2019a, 2019b).

The role of physical activities for human mental health is well known. It is a common saying that "A sound body has a sound mind." So, urban parks provide an ideal platform for walking, running, exercise, and jogging. The presence of green space in the neighbourhood or within walking distance (maximum $1.5 \mathrm{~km}$ by WHO) is essential for human mental well-being. The level of positive association may differ with the difference in size, accessible range of green spaces. According to a study on Perth in Australia, residents' lifestyle is also crucial for wellbeing (Wood et al., 2017). Characteristics of greenness like quality, size, and cleanliness were found significant concerning human health. Different types of green spaces affected human life differently. It has been analyzed that green spaces' cleanliness releases mental stress and removes depression, according to Sheffield's study in the United Kingdom. The study suggested that policymakers should focus not only on the availability of green spaces but also on accessibility, size, quality, and cleanliness (Meyer-Grandbastien et al., 2020). The accessibility of green spaces is essential in urban areas within the free range (400-1600 m) for different buffer zones. The study found positive relations between green spaces and mental well-being in Singapore (Zhang \& Tan, 2019). Overall, green landscapes are positively associated with human well-being, but the effect level depends on green spaces' characteristics and usage. Forest patches near the built-up area were positively correlated with mental well-being and negatively with frequent mental distress (Tsai et al., 2018). Even a level of mental performance increases if people can see greenery from home or the workplace (Taylor et al., 2018).

Real-life changes affect human well-being through intervening in the quality and quantity of green spaces. In Netherland, a study was conducted on deprived neighbourhood showed that no short-term positive impacts were found due to the intervention of green spaces among adults regarding physical activities and self-reported mental well-being. The change in quality and quantity did not positively affect a deprived neighbourhood district of the Netherland. However, positive signs were identified in some subgroups (Gubbels et al., 2016). The role of socio-economic characteristics and urban green spaces is investigated positively for mental well-being in the aged population. An aged group of vulnerable mental health issues was found comparatively better within urban green spaces. Urban greenness is given an essential component in the recovery of mental health issues. Aged people can improve their mental health through nature-based activities (Lee \& Lee, 2019). 
Social well-being

Social well-being is a state in which humans can coexist peacefully in communities with opportunities for advancement. It is characterized by equal access to basic needs and services by avoiding conflict in community life (Social Well-Being, n.d.; Wellman et al., 2014). Social isolation is one of the most significant issues in this modern and busy lifestyle for the urban population. A cross-sectional study conducted in South Korea concluded that green spaces enhance social well-being by providing an ideal platform for social interaction (Hong et al., 2019). Maximum time spent in green parks is considered an essential element to gain maximum benefits for social well-being. Humans can obtain maximum benefits from urban green spaces by removing social isolation at the platform of urban parks. A study conducted in Iran analyzed that maximum time spent in green spaces enhanced social interaction and improved human social life (Dadvand et al., 2019). Recreational activities in urban parks provide an opportunity for social interaction and create better social cohesion (Vujcic et al., 2019). Frequent use of urban parks reduces the stress level in the human body. It removes mental well-being barriers that a study in Scotland has analyzed. The study suggested that urban green parks reduce the sense of social isolation and mitigated mental problems by providing opportunities for yearround activities (Thompson, 2016). Larson et al. (2016) conducted a study on the relationships of urban green parks and human (physical, psychological, and social) well-being. The study selected 44 southern United States cities to investigate the quality, quantity, and accessibility of urban green spaces for human physical, psychological, and social well-being. The results showed strong positive relationships between urban parks and overall well-being. The relations of quality and accessibility were found positive for human well-being. The study suggested that wellmaintained and expensive parks are positively associated with human physical, psychological and social well-being (Larson et al., 2016).

\section{Subjective well-being (happiness and life satisfaction)}

Subjective well-being is a name of personal perceptions about his owns life or a person's evaluations of his own life. 'How much a person is satisfied or happy from his own life is a state of Subjective well-being (Clark et al., 2019; Diener, 2000; "What Is Subjective Well-Being?" 2010). Subjective well-being is known as overall human life satisfaction and happiness. Human life on the earth depends upon a suitable natural environment. Urban green spaces are a significant source of ecosystem services and a natural environment. Everyone is almost aware of how green infrastructure is enriched with numerous benefits for human life. A strong positive association has resulted between green spaces and life satisfaction in a study conducted in South Korea. The study showed a highlevel life satisfaction with urban green landscapes (Hong et al., 2019). The existence of green spaces within a $300 \mathrm{~m}$ radius from the resident's home has significant effects on life satisfaction, analyzed in London. This study indicates that most people who live within a $300 \mathrm{~m}$ radius are highly satisfied with their overall life, but the level of satisfaction decreases with the increase of radius (Houlden et al., 2019). Life satisfaction is a complex area of research for social sciences. Urban greenness relates to socio-economic and environmental aspects. Longtime usage of green spaces is positively associated with life satisfaction, which was assessed in Iran during a study to investigate the impacts of different green spaces on human life (Dadvand et al., 2019).

Life satisfaction always received well respect from social sciences' researchers, and it has been assessed on various scales due to its healthy contribution to the quality of human life. Urban green spaces are an essential pillar of life satisfaction assessed by a study conducted in Szeged (Hungry). The study was based on 227 self-reported respondents. A positive effect on human attitude and life satisfaction was found by contributing to the quality of life with the mediation of recreational activities and aesthetics (Kothencz et al., 2017). The connectivity of humans with nature is obligatory for performing and maintaining life events. During a cross-sectional study with 4912 adults respondents in Melbourne (Australia), it is has resulted that the connectivity of humans with green infrastructure and biodiversity is strongly associated with subjective well-being than public green spaces, which highlighted the overall role of urban greenness for better subjective well-being (Mavoa et al., 2019).

Subjective well-being and all types of green landscapes are positively associated with human feelings and happiness. The interaction of greenery 
improves positive feelings and boosts a natural way of living (Navarrete-Hernandez \& Laffan, 2019). Urban green spaces serve humans in various ways by providing clean air for breathing, reducing noise, enhancing socio-economic and environmental functions, and regulating the local climate (Dong \& Hauschild, 2017). A study was conducted to examine the people's perception of life satisfaction with maintaining urban green landscapes. The study found that the people who are closely kept in touch with green spaces found 'very satisfied' instead of 'quite satisfied' from urban green spaces (Ayala-Azcárraga et al., 2019; Rey Gozalo et al., 2018). It has been significantly recommended that a bit of visit to green space can potentially improve subjective well-being. These results were analyzed by a study in England with a 7272 sample size to observe the connections between a natural environment of subjective wellbeing (White et al., 2017).

\section{Environmental well-being}

Environmental well-being is a significant state in our surroundings that allow humans to live in harmony on the earth by improving human-environment interaction (Neller \& Neller, n.d.). Green spaces are a necessary element of the environment and a compulsory part of making the earth livable for human life. It has been acknowledged that green spaces are a source of various benefits for humans directly and indirectly (Koprowska et al., 2018). In Guangzhou (China), a study was conducted on human and environmental well-being. It is strongly recommended that green spaces are a pillar of urban structure because they mitigate environmental risk and protect human life (Duan et al., 2018). Green spaces and biodiversity help to improve a natural environment, protect different species from climate change effects, and run human life smoothly (Dong \& Hauschild, 2017; Mavoa et al., 2019). Urban vegetation provides clean air, decreases air temperature, boosts up raining patterns, and enhances the beauty of the place. A study analyzed that human feelings and satisfaction levels are associated with green spaces in Caceres (Spain). The study found that the highest satisfaction with urban parks resulted positively (Rey Gozalo et al., 2018).

The presence of vegetation at the street-level serves as a ventilator by filtering air, reducing temperature with shades, providing social interaction, and regulating the local climate. In this way, green spaces serve by improving humans' social and natural environment (Taylor et al., 2018; Tsai et al., 2018; Wang et al., 2019a, 2019b). Urban greenness is essential for pollutants removal from the air. In a Strasbourg (France) study, green spaces removed $\mathrm{PM}_{10}(7 \%)$ and $88 \mathrm{t}$ overall pollutants from the atmosphere annually with $27.80 \%$ green area. The study concluded that urban greenery has a pivotal role in providing clean air for residents. The study suggested that green spaces cannot provide a complete solution to air pollution but can maintain a sustainable city environment. However, we can achieve the target of a sustainable city environment doing balance green spaces and anthropogenic sources (Selmi et al., 2016).

Urban green composition and tree structure have been observed significant for air filtration and climate regulation (Enssle \& Kabisch, 2020). In Almada (Portugal), positive relations have been analyzed of urban green spaces with air purification, climate regulation, and human well-being. According to the study conclusion, proper management of green spaces increases pollutants removal capability, reduces urban heat island (UHI) effects, and delivers a nature-based solution of environment unsustainability (Georgi \& Dimitriou, 2010; Vieira et al., 2018). Green spaces are one of the significant natural cooling sources for cities. In the mid-latitudinal cities, urban heat island is a challenging issue in summer seasons. Due to urban heat island effects, the performance of green spaces as ventilators is firmly acknowledged. In Lisbon (Portugal), a study evaluated that $50 \mathrm{~m}^{2}$ vegetation cover area can decrease $1{ }^{\circ} \mathrm{C}$ air temperature. In this way, urban green spaces enhance the well-being capability of the area (Reis \& Lopes, 2019).

\section{Discussion}

After reviewing the 46 studies, it has been assessed that a wide range of relations exists between urban green spaces and human well-being, which is significant for maintaining the city environment and promoting an active lifestyle by stimulating physical activities. The people in the neighbourhood of green spaces have been observed healthier, but the level under the characteristics like types of vegetation, size of the park, quality, and spatial availability may differ. Green spaces are recognized as an essential element 
for human well-being in urban areas. It has been directed that urban green spaces support human physical, psychological, mental, social, subjective well-being to provide a suitable place for physical activities like walking, jogging, and running. Studies in numerous perspectives have been indicated that regular visit of green places delivers various services for human well-being in the form of physical fitness, mental relaxation, and personal growth. Physical wellbeing and adjoining parks in urban areas offer various opportunities to promote physical activities and reduce obesity rates among the youth population. Free play in a natural environment is beneficial for cognitive and physical development. The relationships between urban green spaces and human well-being analyzed well in various studies by recommending that; (1) a daily base interaction with green landscapes is needed for physical well-being and other health benefits, (2) a weekly visit can enhance human wellbeing and mental growth, and (3) even a view of the green environment improves work performance in office and prevent mental stress effects.

Urban green spaces interaction is mostly found positive relations with human psychological restoration along with feelings well, improved mental energy, work performance, and restore attention. Green spaces improve human psychology by reducing mental stress and rejuvenating attention. Urban greenness promotes human mental satisfaction to promote intellectual and decrease antagonism behaviour. The reviewed studies have shown positive associations between human psychology and green spaces, respectively, but not a complete solution to all human psychological issues. They work like mediation and improve human psychology to increase attention. Easy access to urban parks works as a buffer zone against depression, mental illness, and psychological disorders. In developing countries, the younger population is severely involved in psychological issues. They are not psychologically fit; therefore, this area of research is demanding more attention from researchers to identify an intensive role of urban green spaces and human psychological well-being.

The reviewed studies show that urban green spaces help to enhance mental well-being by providing a suitable environment for physical activities. So, mental well-being is attached to physical well-being, and physical well-being boosts up by physical activities. Similarly, several theories suggest that mental well- being may improve with green spaces' exposure and interaction. In this way, urban green spaces provide benefits for human health and advance human abilities. Urban greenness increases residents' work performance by advancing human mental, physical, and psychological well-being. According to the reviewed literature, contact with nature is helpful for the young population. The nearness of nature boosts mental growth and well-being by lowering stress, improving concentration, and enhancing attention spans.

In the review, life satisfaction differs from how people understand a set of life conditions. Life satisfaction is an essential indicator for the judgment of how people are satisfied with their lives. Some studies on subjective well-being provide an initial indication of a positive correlation with green spaces. According to Taylor et al. (2018), green spaces are positively connected with subjective well-being in Sydney and Melbourne. Higher subjective well-being relations are found from urban green spaces along with societal public policy effects. The people who live near green spaces or keep in touch with green landscapes are comparatively more satisfied with their lives, but the satisfaction level differs with life objectives.

Green Places in cities has been recognized as a necessary part, and it is challenging to make cities livable without green infrastructure. Green spaces provide clean air for breathing by removing pollutants and cool down the air temperature. They improve the urban environment and life satisfaction evaluated by Rey Gozalo et al. (2018). The review shows that green spaces work as a significant pillar for the environment of the cities. They are considered as a ventilator of cities and a natural source of cooling the environment.

\section{Conclusion}

This systematic review presents an overview of the relationships of urban green spaces with human wellbeing. The review depicts how urban green spaces are facilitating the urban population in various ways. The studies have shown significant relationships between urban green spaces and human (physical, psychological, mental, social, subjective, and environmental) well-being. The review found that even a single view of greenery from a window increases work performance and prevents adverse health effects from 
stressful life events proved by Ulrich and Kaplan. So, green spaces provide a peaceful platform to be relaxed for human psychological and mental well-being. The natural environment works as mediation and accelerates the restoration of stressful life effects. Therefore, it has been extracted that green spaces are an essential pillar of urban society. Urban green spaces facilitate all ages of humans. The interaction with green spaces of students daily or even once a week is necessary for positive mental growth. In the old age population, green parks increase health and well-being by providing space for social interaction. Also, Green spaces promote human well-being by regulating city climate, cooling temperature, and filtering the air. It has acknowledged that green spaces are a necessary part of sustainable and livable cities. The role of urban planners and policymakers has become more critical for sustainable and balanced urbanization in the future.

On the other side, green spaces' availability is not as crucial for human well-being as through mediations. The most critical mediations are; daily or weekly interaction, recreation activities, social interaction, jogging or cycling, quiet environment, cleanliness, 5-10 min walking distance, and mixed species and landscapes. Through these medications, maximum benefits can be obtained from urban green spaces.

Urban green spaces provide a wide range of services for human well-being in several forms with an active and passive role. The role of green spaces is not limited to human well-being. Therefore, it is a little bit complicated to review every aspect of the relationship between urban green spaces and human wellbeing in a single study. However, this study attempts to provide a quick review of the impacts of urban green spaces on human (physical, psychological, mental, social, subjective, and environmental) well-being. This study may not present a complete picture but a healthy overview of the association between urban green spaces and human well-being, evaluated by the previous studies.

\section{Future directions}

According to most studies, the review identified that green spaces are necessary for human well-being in urban areas within $400-1600 \mathrm{~m}$. So, there is needed to (1) identify the availability of urban green spaces within accessible range in the cities, (2) highlight hotspot areas having no access, and (3) recognize its possible solution or alternatives using modern technologies and techniques. Consequently, urban green spaces' performance varies by varying the community's structure, quality and quantity, and usage behaviour. So, there is also needed to (1) recognize species qualities according to requirements, (2) analyze the behaviour of society before designing urban green spaces, and (3) construct a comprehensive formula/equation for calculation of the optimal ratio between green and grey structure under the different circumstances. In short, these are all the questions that need to answer in the future. Moreover, there is essential to analyse urban green spaces under different scales, costs and benefits, and spatial configuration.

\section{Declarations}

Conflict of interest We, Muhammad Jabbar, Mariney Mohd Yusoff and Aziz Shafie as authors of the article entitled: "Assessing the Role of Urban Green Spaces for Human Wellbeing: A Systematic Review," declares that I have no known competing financial interests or personal relationships that could have appeared to influence the work reported in this paper. Therefore, the authors declare that they have no conflicts of interest.

Ethical approval This article does not contain any studies with human participants or animals performed by any of the authors.

\section{References}

Akpinar, A. (2016). How is the quality of urban green spaces associated with physical activity and health? Urban Forestry \& Urban Greening, 16, 76-83.

Ayala-Azcárraga, C., Diaz, D., \& Zambrano, L. (2019). Characteristics of urban parks and their relation to user wellbeing. Landscape and Urban Planning, 189, 27-35. https:// doi.org/10.1016/j.landurbplan.2019.04.005

Baycan, T., Girard, L. F., \& Nijkamp, P. (2012). Chapter 1: Creative and sustainable cities: A new perspective. In Sustainable city and creativity. Ashgate: Surrey, UK.

Bhanojirao, V. V. (1991). Human development report 1990: Review and assessment. World Development, 19(10), 1451-1460. https://doi.org/10.1016/0305750X(91)90087-X

Brindley, P., Cameron, R. W., Ersoy, E., Jorgensen, A., \& Maheswaran, R. (2019). Is more always better? Exploring field survey and social media indicators of quality of urban green space in relation to health. Urban Forestry \& Urban Greening, 39, 45-54. https://doi.org/10.1016/j.ufug.2019. 01.015 
Cameron, R. W., Brindley, P., Mears, M., McEwan, K., Ferguson, F., Sheffield, D., Jorgensen, A., Riley, J., Goodrick, J., \& Ballard, L. (2020). Where the wild things are! Do urban green spaces with greater avian biodiversity promote more positive emotions in humans? Urban Ecosystems, 23(2), 301-317.

Campagnaro, T., Vecchiato, D., Arnberger, A., Celegato, R., Da Re, R., Rizzetto, R., Semenzato, P., Sitzia, T., Tempesta, T., \& Cattaneo, D. (2020). General, stress relief and perceived safety preferences for green spaces in the historic city of Padua (Italy). Urban Forestry \& Urban Greening, 52, 126695.

Chambers, R., \& Conway, G. (1992). Sustainable rural livelihoods: Practical concepts for the 21st century. Institute of Development Studies (UK). https://opendocs.ids.ac.uk/ opendocs/handle/20.500.12413/775

Chang, P.-J., Tsou, C.-W., \& Li, Y.-S. (2020). Urban-greenway factors' influence on older adults' psychological well-being: A case study of Taichung Taiwan. Urban Forestry \& Urban Greening, 49, 126606.

Clark, W. A., Yi, D., \& Huang, Y. (2019). Subjective well-being in China's changing society. Proceedings of the National Academy of Sciences, 116(34), 16799-16804.

Dadvand, P., Hariri, S., Abbasi, B., Heshmat, R., Qorbani, M., Motlagh, M. E., Basagaña, X., \& Kelishadi, R. (2019). Use of green spaces, self-satisfaction and social contacts in adolescents: A population-based CASPIAN-V study. Environmental Research, 168, 171-177. https://doi.org/10. 1016/j.envres.2018.09.033

Dadvand, P., Rivas, I., Basagaña, X., Alvarez-Pedrerol, M., Su, J., Pascual, M. D. C., Amato, F., Jerret, M., Querol, X., \& Sunyer, J. (2015). The association between greenness and traffic-related air pollution at schools. Science of the Total Environment, 523, 59-63. https://doi.org/10.1016/j. scitotenv.2015.03.103

Desai, M. (1991). Human development: Concepts and measurement. European Economic Review, 35(2-3), 350-357. https://doi.org/10.1016/0014-2921(91)90136-7

Dhingra, M., \& Chattopadhyay, S. (2016). Advancing smartness of traditional settlements-case analysis of Indian and Arab old cities. International Journal of Sustainable Built Environment, 5(2), 549-563. https://doi.org/10.1016/j. ijsbe.2016.08.004

Diener, E. (2000). Subjective well-being: The science of happiness and a proposal for a national index. American Psychologist, 55(1), 34.

Dong, Y., \& Hauschild, M. Z. (2017). Indicators for environmental sustainability. Procedia CIRP, 61, 697-702.

Dong, H., \& Qin, B. (2017). Exploring the link between neighborhood environment and mental wellbeing: A case study in Beijing, China. Landscape and Urban Planning, 164, 71-80.

Duan, J., Wang, Y., Fan, C., Xia, B., \& de Groot, R. (2018). Perception of urban environmental risks and the effects of urban green infrastructures (UGIs) on human well-being in four public green spaces of Guangzhou China. Environmental Management, 62(3), 500-517. https://doi.org/10. 1007/s00267-018-1068-8

Enssle, F., \& Kabisch, N. (2020). Urban green spaces for the social interaction, health, and well-being of older people: An integrated view of urban ecosystem services and socio- environmental justice. Environmental Science \& Policy, 109, 36-44. https://doi.org/10.1016/j.envsci.2020.04.008

García de Jalón, S., Chiabai, A., Mc Tague, A., Artaza, N., de Ayala, A., Quiroga, S., Kruize, H., Suárez, C., Bell, R., \& Taylor, T. (2020). Providing access to urban green spaces: A participatory benefit-cost analysis in Spain. International Journal of Environmental Research and Public Health, 17(8), 2818.

Gascon, M., Sánchez-Benavides, G., Dadvand, P., Martínez, D., Gramunt, N., Gotsens, X., Cirach, M., Vert, C., Molinuevo, J. L., Crous-Bou, M., \& Nieuwenhuijsen, M. (2018). Longterm exposure to residential green and blue spaces and anxiety and depression in adults: A cross-sectional study. Environmental Research, 162, 231-239. https://doi.org/10. 1016/j.envres.2018.01.012

Georgi, J. N., \& Dimitriou, D. (2010). The contribution of urban green spaces to the improvement of the environment in cities: A case study of Chania Greece. Building and Environment, 45(6), 1401-1414.

Gubbels, J. S., Kremers, S. P., Droomers, M., Hoefnagels, C., Stronks, K., Hosman, C., \& de Vries, S. (2016). The impact of greenery on physical activity and mental health of adolescent and adult residents of deprived neighborhoods: A longitudinal study. Health \& Place, 40, 153-160.

Gwatkin, D. R. (2002). Who would gain most from efforts to reach the millennium development goals for health? World Bank, Washington, DC. www.worldbank.org.

Helbich, M., Klein, N., Roberts, H., Hagedoorn, P., \& Groenewegen, P. P. (2018). More green space is related to less antidepressant prescription rates in the Netherlands: A Bayesian geoadditive quantile regression approach. Environmental Research, 166, 290-297. https://doi.org/10. 1016/j.envres.2018.06.010

Holt, E. W., Lombard, Q. K., Best, N., Smiley-Smith, S., \& Quinn, J. E. (2019). Active and passive use of green space, health, and well-being amongst university students. International Journal of Environmental Research and Public Health, 16(3), 424. https://doi.org/10.3390/su11154189

Hong, S.-K., Lee, S.-W., Jo, H.-K., \& Yoo, M. (2019). Impact of Frequency of visits and time spent in urban green space on subjective well-being. Sustainability, 11(15), 4189. https:// doi.org/10.3390/su11154189

Hopkins, M. (1991). Human development revisited: A new UNDP report. World Development, 19(10), 1469-1473. https://doi.org/10.1016/0305-750X(91)90089-Z

Houlden, V., de Albuquerque, J. P., Weich, S., \& Jarvis, S. (2019). A spatial analysis of proximate greenspace and mental wellbeing in London. Applied Geography, 109, 102036. https://doi.org/10.1016/j.apgeog.2019.102036

Jennings, V., \& Bamkole, O. (2019). The relationship between social cohesion and urban green space: An avenue for health promotion. International Journal of Environmental Research and Public Health, 16(3), 452.

Konijnendijk, C. C., Annerstedt, M., Nielsen, A. B., \& Maruthaveeran, S. (2013). Benefits of urban parks: A systematic review. A Report for IPFRA. IFPRA.

Koprowska, K., Łaszkiewicz, E., Kronenberg, J., \& Marcińczak, S. (2018). Subjective perception of noise exposure in relation to urban green space availability. Urban Forestry \& Urban Greening, 31, 93-102. 
Kothencz, G., Kolcsár, R., Cabrera-Barona, P., \& Szilassi, P. (2017). Urban green space perception and its contribution to well-being. International Journal of Environmental Research and Public Health, 14(7), 766. https://doi.org/10. 3390/ijerph14070766

Krellenberg, K., Welz, J., \& Reyes-Päcke, S. (2014). Urban green areas and their potential for social interaction: A case study of a socio-economically mixed neighbourhood in Santiago de Chile. Habitat International, 44, 11-21. https://doi.org/10.1016/j.habitatint.2014.04.004

Larson, L. R., Jennings, V., \& Cloutier, S. A. (2016). Public parks and wellbeing in urban areas of the United States. PLoS One, 11(4), e0153211.

Lee, H. J., \& Lee, D. K. (2019). Do sociodemographic factors and urban green space affect mental health outcomes among the urban elderly population? International Journal of Environmental Research and Public Health, 16(5), 789.

Lin, W., Chen, Q., Jiang, M., Tao, J., Liu, Z., Zhang, X., Wu, L., Xu, S., Kang, Y., \& Zeng, Q. (2020). Sitting or walking? Analyzing the neural emotional indicators of urban green space behavior with mobile EEG. Journal of Urban Health, 97(2), 191-203.

Lou, H., Yang, S., Zhao, C., Wang, Z., Liu, X., Shi, L., Wu, L., Hao, F., \& Cai, M. (2017). Combining multi-source data to explore a mechanism for the effects of micrometeorological elements on nutrient variations in paddy land water. Paddy and Water Environment, 15(3), 513-524. https:// doi.org/10.1007/s10333-016-0568-5

Ma, B., Zhou, T., Lei, S., Wen, Y., \& Htun, T. T. (2019). Effects of urban green spaces on residents' well-being. Environment, Development, and Sustainability, 21(6), 2793-2809.

Madureira, H., Nunes, F., Oliveira, J. V., \& Madureira, T. (2018). Preferences for urban green space characteristics: A comparative study in three portuguese cities. Environments, 5(2), 23. https://doi.org/10.3390/ environments5020023

Mavoa, S., Davern, M., Breed, M., \& Hahs, A. (2019). Higher levels of greenness and biodiversity associate with greater subjective wellbeing in adults living in Melbourne, Australia. Health \& Place, 57, 321-329. https://doi.org/10. 1016/j.healthplace.2019.05.006

McGillivray, M., \& White, H. (1993). Measuring development? The UNDP's human development index. Journal of International Development, 5(2), 183-192. https://doi.org/ 10.1002/jid.3380050210

Mears, M., Brindley, P., Jorgensen, A., \& Maheswaran, R. (2020). Population-level linkages between urban green space and health inequality: The case for using multiple indicators of neighbourhood greenspace. Health \& Place, 62, 102284.

Mensah, C. A., Andres, L., Perera, U., \& Roji, A. (2016). Enhancing quality of life through the lens of green spaces: A systematic review approach. International Journal of Wellbeing, 6(1), 142-163. https://doi.org/10.5502/ijw. v6i1.445

Meyer-Grandbastien, A., Burel, F., Hellier, E., \& Bergerot, B. (2020). A step towards understanding the relationship between species diversity and psychological restoration of visitors in urban green spaces using landscape heterogeneity. Landscape and Urban Planning, 195, 103728. https://doi.org/10.1016/j.landurbplan.2019.103728
Misiune, I., Julian, J. P., \& Veteikis, D. (2021). Pull and push factors for use of urban green spaces and priorities for their ecosystem services: Case study of vilnius lithuania. Urban Forestry \& Urban Greening, 58, 126899.

Nath, T. K., Zhe Han, S. S., \& Lechner, A. M. (2018). Urban green space and well-being in Kuala Lumpur, Malaysia. Urban Forestry \& Urban Greening, 36, 34-41. https://doi. org/10.1016/j.ufug.2018.09.013

Navarrete-Hernandez, P., \& Laffan, K. (2019). A greener urban environment: Designing green infrastructure interventions to promote citizens' subjective wellbeing. Landscape and Urban Planning, 191, 103618. https://doi.org/10.1016/j. landurbplan.2019.103618

Neller, A. H., \& Neller, R. J. (n.d.). Environment Well-Being and Human Well-Being. 6.

Nutsford, D., Pearson, A. L., \& Kingham, S. (2013). An ecological study investigating the association between access to urban green space and mental health. Public Health, 127(11), 1005-1011. https://doi.org/10.1016/j.puhe.2013. 08.016

Paul, S., \& Nagendra, H. (2017). Factors influencing perceptions and use of urban nature: Surveys of park visitors in Delhi. Land, 6(2), 27. https://doi.org/10.3390/land6020027

Physical well-being. (n.d.). AANA. Retrieved 20 September 2020, from https://www.aana.com/practice/health-andwellness-peer-assistance/about-health-wellness/physicalwell-being.

Pietilä, M., Neuvonen, M., Borodulin, K., Korpela, K., Sievänen, T., \& Tyrväinen, L. (2015). Relationships between exposure to urban green spaces, physical activity, and selfrated health. Journal of Outdoor Recreation and Tourism, $10,44-54$.

Reis, C., \& Lopes, A. (2019). Evaluating the cooling potential of urban green spaces to tackle urban climate change in Lisbon. Sustainability, 11(9), 2480. https://doi.org/10.3390/ su11092480

Rey Gozalo, G., Barrigón Morillas, J. M., Montes González, D., \& Atanasio Moraga, P. (2018). Relationships among satisfaction, noise perception, and use of urban green spaces. Science of the Total Environment, 624, 438-450. https:// doi.org/10.1016/j.scitotenv.2017.12.148

Roe, J., Aspinall, P. A., \& Ward Thompson, C. (2016). Understanding relationships between health, ethnicity, place, and the role of urban green space in deprived urban communities. International Journal of Environmental Research and Public Health, 13(7), 681. https://doi.org/10.3390/ ijerph13070681

Sanders, T., Feng, X., Fahey, P. P., Lonsdale, C., \& Astell-Burt, T. (2015). The influence of neighbourhood green space on children's physical activity and screen time: Findings from the longitudinal study of Australian children. International Journal of Behavioral Nutrition and Physical Activity, 12(1), 126.

Schebella, M., Weber, D., Schultz, L., \& Weinstein, P. (2019). The wellbeing benefits associated with perceived and measured biodiversity in Australian urban green spaces. Sustainability, 11(3), 802. https://doi.org/10.3390/ su11030802

Scopelliti, M., Carrus, G., Adinolfi, C., Suarez, G., Colangelo, G., Lafortezza, R., Panno, A., \& Sanesi, G. (2016). Staying in touch with nature and well-being in different income 
groups: The experience of urban parks in Bogotá. Landscape and Urban Planning, 148, 139-148.

Selmi, W., Weber, C., Rivière, E., Blond, N., Mehdi, L., \& Nowak, D. (2016). Air pollution removal by trees in public green spaces in Strasbourg city, France. Urban for Urban Green, 17, 192-201.

Social well-being. (n.d.). Econation. Retrieved 20 September 2020, from http://www.econation.co.nz/social-well-being/

Southon, G. E., Jorgensen, A., Dunnett, N., Hoyle, H., \& Evans, K. L. (2018). Perceived species-richness in urban green spaces: Cues, accuracy and well-being impacts. Landscape and Urban Planning, 172, 1-10. https://doi.org/10.1016/j. landurbplan.2017.12.002

Taylor, L., Hahs, A. K., \& Hochuli, D. F. (2018). Wellbeing and urban living: Nurtured by nature. Urban Ecosystems, 21(1), 197-208. https://doi.org/10.1007/s11252-018-0788-0

Thompson, C. W. (2016). Greenways to health: The links between access to green space and healthy communities. In Proceedings of the fábos conference on landscape and greenway planning, 5(2), 8. https://scholarworks.umass. edu/fabos/vol5/iss $2 / 8$.

Tsai, W.-L., McHale, M. R., Jennings, V., Marquet, O., Hipp, J. A., Leung, Y.-F., \& Floyd, M. F. (2018). Relationships between characteristics of urban green land cover and mental health in US metropolitan areas. International Journal of Environmental Research and Public Health, 15(2), 340. https://doi.org/10.3390/ijerph15020340

Venter, Z. S., Barton, D. N., Gundersen, V., Figari, H., \& Nowell, M. (2020). Urban nature in a time of crisis: Recreational use of green space increases during the COVID-19 outbreak in Oslo Norway. Environmental Research Letters, 15(10), 104075.

Vieira, J., Matos, P., Mexia, T., Silva, P., Lopes, N., Freitas, C., Correia, O., Santos-Reis, M., Branquinho, C., \& Pinho, P. (2018). Green spaces are not all the same for the provision of air purification and climate regulation services: The case of urban parks. Environmental Research, 160, 306-313. https://doi.org/10.1016/j.envres.2017.10.006

Vujcic, M., Tomicevic-Dubljevic, J., Zivojinovic, I., \& Toskovic, O. (2019). Connection between urban green areas and visitors' physical and mental well-being. Urban Forestry \& Urban Greening, 40, 299-307. https://doi.org/10.1016/j. ufug.2018.01.028

Wang, R., Helbich, M., Yao, Y., Zhang, J., Liu, P., Yuan, Y., \& Liu, Y. (2019a). Urban greenery and mental wellbeing in adults: Cross-sectional mediation analyses on multiple pathways across different greenery measures. Environmental Research, 176, 108535. https://doi.org/10.1016/j. envres.2019.108535

Wang, R., Zhao, J., Meitner, M. J., Hu, Y., \& Xu, X. (2019b). Characteristics of urban green spaces in relation to aesthetic preference and stress recovery. Urban Forestry \& Urban Greening, 41, 6-13.

Wang, Y., \& Akbari, H. (2016). Analysis of urban heat island phenomenon and mitigation solutions evaluation for Montreal. Sustainable Cities and Society, 26, 438-446. https://doi.org/10.1016/j.scs.2016.04.015

Wellman, K. F., Biedenweg, K., \& Wolf, K. (2014). Social sciences in puget sound recovery. Coastal Management,
42(4), 298-307. https://doi.org/10.1080/08920753.2014. 923129

What is psychological wellbeing? I Robertson Cooper. (n.d.). Retrieved 20 September 2020, from https://www. robertsoncooper.com/blog/what-is-psychologicalwellbeing/.

What is Subjective Well-Being? Understanding and Measuring Subjective Well-Being. (2010, 16 January). PositivePsychology.Org.Uk. http://positivepsychology.org.uk/ subjective-well-being/.

White, M. P., Alcock, I., Wheeler, B. W., \& Depledge, M. H. (2013). Would you be happier living in a greener urban area? A fixed-effects analysis of panel data. Psychological Science, 24(6), 920-928.

White, M. P., Pahl, S., Wheeler, B. W., Depledge, M. H., \& Fleming, L. E. (2017). Natural environments and subjective wellbeing: Different types of exposure are associated with different aspects of wellbeing. Health \& Place, 45, 77-84. https://doi.org/10.1016/j.healthplace.2017.03.008

WHOIUrban green spaces. (n.d.). WHO; World Health Organization. Retrieved 27 April 2020, from http://www.who. int/sustainable-development/cities/health-risks/urbangreen-space/en/.

Wolch, J. R., Byrne, J., \& Newell, J. P. (2014). Urban green space, public health, and environmental justice: The challenge of making cities 'just green enough.' Landscape and Urban Planning, 125, 234-244. https://doi.org/10.1016/j. landurbplan.2014.01.017

Wood, L., Hooper, P., Foster, S., \& Bull, F. (2017). Public green spaces and positive mental health: Investigating the relationship between access, quantity, and types of parks and mental wellbeing. Health \& Place, 48, 63-71. https://doi. org/10.1016/j.healthplace.2017.09.002

World Health Organization, Promotion of mental well-being. (n.d.). SEARO; World Health Organization, South-East Asia Regional Office. Retrieved 20 September 2020, from http://www.searo.who.int/mental_health/promotion-ofmental-well-being/en/.

Yeh, C.-T., Cheng, Y.-Y., \& Liu, T.-Y. (2020). Spatial characteristics of urban green spaces and human health: An exploratory analysis of canonical correlation. International Journal of Environmental Research and Public Health, 17(9), 3227.

Zhang, L., \& Tan, P. Y. (2019). Associations between urban green spaces and health are dependent on the analytical scale and how urban green spaces are measured. International Journal of Environmental Research and Public Health, 16(4), 578. https://doi.org/10.3390/ ijerph16040578

Zhong, J., Li, Z., Sun, Z., Tian, Y., \& Yang, F. (2020). The spatial equilibrium analysis of urban green space and human activity in Chengdu. China. Journal of Cleaner Production, 259, 120754.

Publisher's Note Springer Nature remains neutral with regard to jurisdictional claims in published maps and institutional affiliations. 